\title{
The Effect of Auditor Quality on the Follow-Up of Audit Recommendation
}

\author{
Dyah Setyaningrum", Lindawati Gani ${ }^{* *}$, Dwi Martani ${ }^{* * *}$, Cris Kuntadi $^{* * * *}$ \\ ******* Fakultas Ekonomi dan Bisnis, Universitas Indonesia \\ **** Inspektorat Jenderal Kementerian Transportasi RI
}

\begin{tabular}{l} 
A R T I C L E I N F O \\
\hline JEL Classification: \\
M420 \\
Keywords: \\
auditor quality, \\
audit recomendation, \\
follow-up, \\
local government, \\
supreme audit institution
\end{tabular}

dystia_01@yahoo.com

\section{A B S T R A C T}

The purpose of this study is to measure auditor quality of The Audit Board of the Republic of Indonesia (BPK) and investigates the effect of auditor quality on the follow-up of audit recommendation. This study uses sample of local government financial statements in Indonesia from 2010-2012. Using principle component analysis method, the result shows that there are four components extracted that form auditor quality which is experience, training, motivation, and education. All four components are then combined into a single auditor quality index that represents comprehensive measure of auditor quality. The test result shows positive effect between auditor quality and follow-up of audit recommendation. This indicates that high quality auditor is able to produce appropriate recommendations that can be easily followed up by the auditee. The more recommendations are acted upon, the better the quality of local government financial statements.

(C) 2013 IRJBS, All rights reserved.

\section{INTRODUCTION}

In several literature of auditing, audit quality is defined as the probability of discovering the breach and to report it to the users of financial statements (De Angelo, 1981). In this original definition, auditor's competency is considered fixed and do not vary with each audit engagement. According to Watkins et al., (2004), audit quality component consists of auditor monitoring strength and auditor reputation. Audit monitoring strength represents auditor's ability to provide information that minimizes the difference between a client's reported economic circumstances and the "true" unobservable, economic circumstances of the client. The greater auditor monitoring strength the more closely financial report will reflect the true economic circumstances of the client and the higher information quality. Auditor reputations affect the credibility of the information or perception of the reliability of information. Auditor 
reputation is viewed as a firm-wide characteristic that is consistent on all audit engagement, whereas the auditor monitoring strength can vary on each audit engagement. The case audit failure of Andersen LLP could be one of the example that high reputation auditor could provide weak monitoring strength in particular engagement.

Refer to Watkins et al., (2004), audit quality can be measured by the auditor quality; where the auditor quality represents competency of human capital. Using principle component analysis, Cheng et al., (2013) extracts three major factors that form the auditor quality which is education, experience and training. In contrast with private sector audit, public sector audit generally monopolistic in nature (Clark, et al., 2007), meaning that the authority to conduct financial audits of the government entities can only be done by certain institutions. BPK is the only institutions that are given the authority to audit the management and financial responsibility of the government entities. Characteristics of private sector auditors and public sector auditors are also very different. Public sector auditors usually civil servants who earn fixed salary, very small risk of being laid off and do not suffer any loss of reputation. The lack of incentive to do a good job could be a threat that result to low audit quality. According to Streim (1994), motivation becomes important aspects that affect the audit quality in the government sector, and will be used as one determinant of the auditor quality in this study. Auditor quality as measure of audit quality has not been much explored in empirical research. So, the first objective of this study is to measure auditor quality of BPK who performs audit of local governments' financial statements (LKPD).

High auditor quality is expected to consistently generate appropriate recommendations in suitable with auditee condition and correct cause of deficiency in order to improve financial management accountability. Based on BPK's performance management report (2012), it is mention that BPK's auditor are encouraged to formulate recommendations that can be acted upon by the auditee and then it will give impact on improvement of local government operational performance. As far as our concerns, empirical research on the effect of auditor quality on followup of audit recommendation is still limited. Lin and Liu (2012), use the number of team members as measurement of auditor competence as one of the variables that affect the audit rectification, but found no effect between these two variables. The absence of influence of auditor competence on audit rectification could be due to the inappropriate measurement of competencies. There should be more factors to be considered on measuring auditor competences not only number of team member, but also education, experience, and training as proposed by Cheng et al., (2013) as well as motivation as proposed by Streim (1994). Based on BPK's summary of audit report $2^{\text {nd }}$ semester 2012, number of recommendations followed-up by local government in Indonesia from period 2009-2013 in number (nominal) is $53.09 \%$; and $26.96 \%$ respectively. The rest of the recommendation is categorized as: (1) has not been followed up, (2) has been followed up but not accordance with the recommendation, or (3) cannot be followed up. The low percentage of completely follow-up audit recommendation could probably due to failure of BPK's auditor to formulate appropriate recommendation or local governments have not been paying full attention for following-up audit recommendation. Followup of audit recommendation should not be the only responsibility of the local government as the preparer of financial statements, but auditor shall take the role for increasing implemented recommendations by formulating appropriate recommendations that can be easily acted upon by the local government. The second objective of this study is to examine the effect of auditor quality on follow-up of audit recommendation using a comprehensive measure of auditor quality.

Auditor quality measurements in this study developed from several components that consist of 
tenure, workload, professional skills, continuing professional education, level of education and motivation. Using principle component analysis method, the result shows there are four components that form auditor quality namely experience, training, motivation, and education. All four components are then combined into a single auditor quality index that represents comprehensive measure of auditor quality. The empirical test result shows a positive effect between auditor quality and follow-up of audit recommendation. This indicates that high quality auditor is able to produce appropriate recommendations that can be easily followed up by the auditee. The more recommendations are acted upon, the better quality of local government financial statements.

The remainder of this study proceeds as follows: section II briefly explain hypothesis development and research methodology. Section III discusses the empirical results followes by the managerial implication in section IV. Section V concludes the study.

\section{METHODS}

\section{Auditor Quality}

Cheng et al., (2013) shows that auditor quality is positively related to company's performance, where higher auditor quality result in superior performance. In several studies on audit quality including De Angelo (1981), it is assumed that there is no variation in the auditors'competence. Cheng et al., (2013) relaxes this assumption and measure audit quality from the quality of human resources owned by public accounting firm. Auditor quality in Cheng et al., (2013) is extracted from principle component analysis techniques and the result shows that there are three major factors that form auditor quality which is education, experience and training. To answer the first research question, auditor quality measurements will be developed from several auditor quality variable consist of tenure, workload, professional skills, continuing professional education, level of education and motivation.
There are two contradictory opinions between auditor tenure with audit quality. The first view says that there is a negative relationship between long audit engagements with the audit quality. The longer the time the auditor's doing an audit, the more familiar their relationship with the client. This leads to a chance to compromising audit opinion, so the client has greater reporting flexibility (Davis et al., 2002; Dopuch et al., 2001; Chi et al, 2005). These results support the need for mandatory auditor rotation. The second view does not support the need for mandatory audit rotation and found that a short period of audit assignments related to low earnings quality and longer period assignment associated with higher earnings quality (Johnshon, et al., 2002 and Myers et al., 2003). This is might due to the shorter the period of assignment, the auditor's knowledge of the business, operations, accounting policies and internal control system of the client not yet comprehensive compared to the longer audit assignments. In addition, the shorter the period of assignments, the possibility of the auditor to accommodate client's need is higher because they are more focused on the fees rather than protect its reputation (Johnshon, et al., 2002; Carcello and Nagy, 2004). The existence of mixed evidence about the need for audit rotation shows that there is a trade off between independence and competence. The longer the auditor audits a company, it will increase the auditor competence, but at the same time, the client auditor relationship will become closer so that the level of independence decreased. However, increase in competence is not always accompanied by a decrease in independence. This is due to the lost of independency has greater losses than getting additional fees due to additional clients (Watts and Zimmerman, 1985). Because of this audit risk, several auditors have high competence without losing its independence.

Workload can be seen from the number of clients handled by the auditor in certain period of time or the limited time available to carry out the all audit process. Jones et al., (2010) found the 
association between the busy season with stress and fatigue, and it reduces auditor commitment, job satisfaction and individual performance. The limited time to finish the job causes the auditor to perform substandard work (Agoglia, et al., 2010). Lopez and Peters (2012) proved that the work pressure led to poor audit quality and improve management capabilities to manipulate reported earning. Hansen, et al., (2008) also found that audit capacity stress because of having many clients will result in decline of audit quality. In Indonesia, the Law No.17/2003 stated that the local government head are required to submit financial statements BPK, no later than six months after the fiscal year ends. December is the end of the fiscal year, so first quarter and the second quarter is a busy season for BPK's auditors. Van Linden \& Willekens (2013) found a negative relationship between high staff workload and partner with audit quality, so the workload issue should become one of the main concerns for Human Resource Division of BPK.

State Finance Auditing Standard (SPKN) point 4.3 stated that the staff assigned to carry out the audit must have sufficient professional skills required for the task. Choo and Trotman (2001) found that experienced auditors find more atypical findings compare with less experienced auditors. This is consistent with Tubbs (1992) who found that the more experience the auditors, the more errors they can found. Cheng et al., (2013) divided auditors into three age categories (1) between 35-44 years, (2) 45-54 years and (3) above 55 years. Cheng et al., (2013) concludes that auditors with age above 35 years with more 10 years working experience considered as more experienced. Besides age, the professional certification is also another factor used by Cheng et al., (2013) to measure professionalism. Auditors who hold certified public accountant (CPA) assumed already equipped with adequate level of academic knowledge and practices and reflect the auditor professionalism. However, in the government audit, having CPA title is not considered highly necessary, because government audit requires specific expertise.
Professional skill can be measured by role of auditor in conducting audit. BPK regulation 4/2010 art 19 states that every auditor has role in carrying out their duty. The role classifications from the lowest to the highest are junior team members; senior team members; junior team leader; senior team leader; technical control and quality control. In order to get promoted, auditor must pass the certification for each level and also received good assessment from human resources division.

According to SPKN, continuing professional education (CPE) is intended to update auditors' knowledge with current developments in methodology and audit procedures. Through continuing education, auditor will obtain a deeper understanding of accounting issue and increase skills in conducting audit, so audit quality will improve. Cheng et al., (2013) measures CPE by calculating the training cost of each public accounting firm. This measurement is difficult to apply for BPK's auditors, since all education and training activities of for auditors conducted centrally in BPK Training Centre, so that the cost of training is not classified by each local government; instead CPE can be measured using number of training hour followed by auditor.

AICPA's task force reports that one of the factors that can improve the quality of the government auditor's work is level of auditors' education. Two indicators used by Cheng et al., (2013) to measure education is the number of auditors with bachelor degree and post-graduate degree. Using same measurement with Cheng et al., (2013), Setyaningrum (2011) shows no effect of educational level of BPK auditors to audit findings.

Streim (1994) stated that motivation is important aspect that affects the audit quality in public sector. Characteristics of private and public sector auditors are very different. Public auditors usually civil servants who earn a fixed salary, small risk of being laid off, and do not suffer any loss of reputation (or could lose reputation without losing 
money). The lack of incentive to do a good job threatens audit quality. Therefore, motivation should be considered as a determinant of audit quality. Efendy (2010) shows positive relationship between motivation and the audit quality. This is in line with Bennis (2003) in which the motivation drive the person to have high morale to achieve the goals and meet the existing standards. Efendy (2010)also noted that the recommendation on audit results should be followed up in order not to lose auditors motivation. Increasing the effectiveness of the following up the recommendation is one of the strategic objectives outlined in the BPK's key performance indicators (KPI). This KPI is one indicator to assess the impact of BPK's key business processes. Each audit findings accompanied by recommendation and followup on audit recommendation is one key success factor of the duties implementation, functions and role of BPK to encourage state management and financial responsibility. Thus, follow-up on audit recommendation could be one of the auditor's motivations in improving audit quality.

Auditor quality in this research is measured from the quality of the audit team leader. The audit team leader is in charge in conducting audit field to ensure all parties understand the audit process related to the overall planning and tasks assigned. Audit team leader should also ensure that the people involved in the audit engagement have the skills needed to perform a given task, and no conflict of interest or other factors that would hinder any team member in carrying out the tasks assigned by competent and objective manner (EUROSAI, 2004). Based on the above considerations, the quality of the audit team leader is considered reflects the quality of BPK's auditors.

\section{Hypothesis Development}

ASOSAI (2009) stated that the greater the percentage of recommendations accepted and implemented by the auditee, the higher the audit quality. Follow-up after the audit process is local government responsibility for improving public financial accountability. Without follow-up, the audit findings are useless in creating accountability in government auditing process. Empirical research on audit rectification is limited. In China, Huang dan Wang (2010) argue that the correction or rectification effort made by the audit institutions and related parties after problem are recognized is the most important factor in determining the extent to which government auditing can perform its duties and promote government transparency and accountability.

Liu and Lin (2012) found that the China National Audit Office (CNAO) can detect irregularities and misbehavior in the management of public revenues and expenditures and provide recommendations to correct the irregularities. However, not all sanctions, penalties and recommendations made by the audit institution are fulfilled by the government. Empirical result shows that auditee and other stakeholder efforts in following up auditor recommendation can strengthen the effectiveness of government audit and help to reduce corruption in the future. The importance of high audit quality should be followed by the utilization of the audit results by the auditee. Lin and Liu (2012) stated that detection of irregularities in government auditing is only the first step and the second step is asking for responsibility and making correction. It is only through the complete and timely enforcement of audit decisions, the detterent effect of government auditing can be guaranteed. Otherwise, audit decisions will represent worthless piece of paper and violation will occur again and again.

High quality auditors are expected to generate appropriate recommendations suitable with auditee conditions that can correct deficiency and easily implemented by auditee, so the number of completely followed-up audit recommendations will be higher. ASOSAI (2009) stated that the greater the percentage of recommendations accepted and implemented by the auditee is one of the indicators of high audit quality. BPK's performance management report (2012) stated 
that the BPK's auditor is encouraged to formulate recommendations that can be acted upon by the auditee and enable to enhance operational performance. As illustrated in figure 1, followup audit recommendation in year $(\mathrm{t})$ is the rectification process done by management during year $(t)$ based on recommendation given by auditor in year (t-1); therefore follow-up of audit recommendation in year $(\mathrm{t})$ is affected by auditor quality in year (t-1). Therefore, the hypothesis regarding the effect of auditor quality on the followup of audit recommendation is stated as follows:

\section{H1 (Lag) Auditor quality has positive effect on the follow-up of audit recommendation}

\section{Data}

Population in this study is all form of local governments (province/districts/municipalities) in Indonesia for the period 2010-2012. The research period was chosen because since 2010 BPK established regulation No. 4/2010 that consists of detailed rules about BPK's auditor role in conducting audit that become one of our main variable. Furthermore, until this study is conducted, complete audited local government financial statement is available only up to 2012 . Some variables (audit opinion and audit findings) uses lag; so several data need to be collected from year 2009. The purposive sampling method is used to obtain complete data. Data sources of this study are obtained from BPK which consists of:

(1) audited local government financial statement,

(2) semiannual summary of audit report and

(3) human resources data related to audit team leader competence. Other data are taken from Statistical Bureau and the official website of local government and DPRD.

\section{Regression Model}

Regression model to test the hypothesis is as follows:

TLRHP_NOM ${ }_{\mathrm{it}}=\mathrm{a}_{0}+\mathrm{a}_{1} \mathrm{AQ}_{\mathrm{it}-1}+\mathrm{a}_{2} \mathrm{OPINI}_{\mathrm{it}-1}+$

$$
\begin{aligned}
& \mathrm{a}_{3} \text { FINDING }_{\mathrm{it}-1}+\mathrm{a}_{4} \text { SIZE }_{\mathrm{it}}+ \\
& \mathrm{a}_{5} \text { DEPEND }_{\mathrm{it}}+\mathrm{a}_{6} \text { POPL }_{\mathrm{it}}+ \\
& \mathrm{a}_{7} \text { AGES }_{\mathrm{it}}+\mathrm{a}_{8} \text { SUPP }_{\mathrm{it}}+€_{\mathrm{it}}
\end{aligned}
$$

Where:

TLRHP_NOM ${ }_{\text {it }}=$ Follow-up of audit recommendation at time $\mathrm{t}$

$\mathrm{AQ}_{\mathrm{it}-1} \quad=$ Auditor Quality Index at time t-1

OPINI $_{\mathrm{it}-1} \quad=$ Audit Opinion at time t-1

FINDING $_{\mathrm{it}-1} \quad=$ Audit Findings at time $\mathrm{t}-1$

SIZE $_{\mathrm{it}} \quad=$ Size of Local Government at time $t$

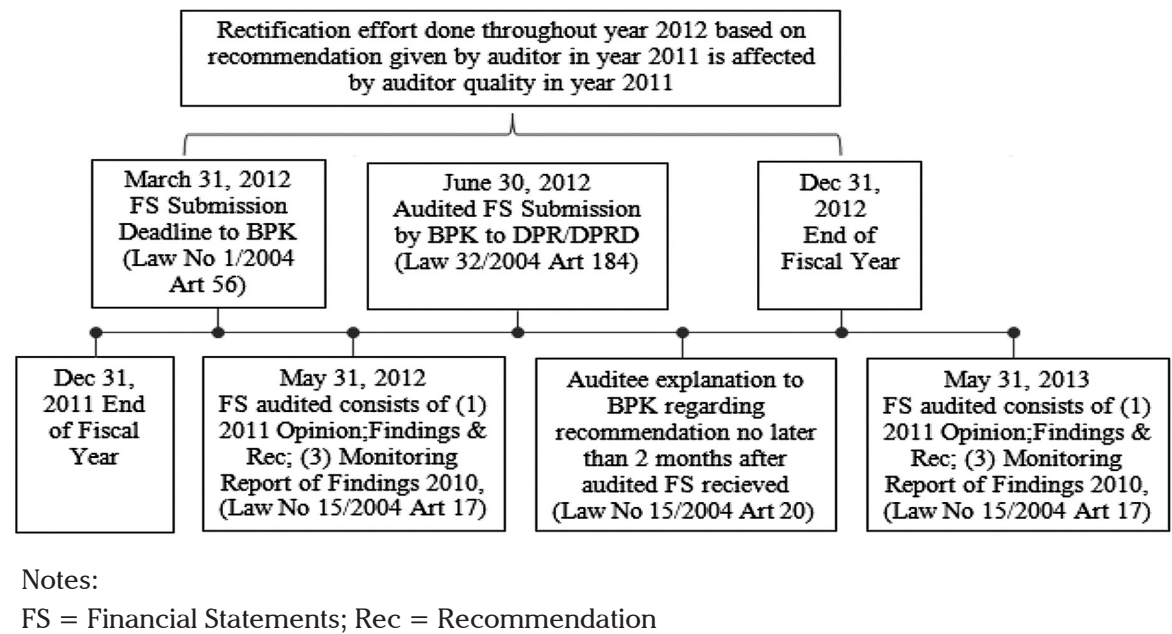

Figure 1. Illustration of Follow-up of Audit Recommendation 


\begin{tabular}{|c|c|}
\hline DEPEND $_{i t}$ & $\begin{aligned}= & \text { Intergovernmental revenue } \\
& \text { transfer at time } \mathrm{t}\end{aligned}$ \\
\hline AGES $_{\text {it }}$ & $\begin{aligned}= & \text { Age of Local Government at } \\
& \text { time } t\end{aligned}$ \\
\hline $\mathrm{SUPP}_{\mathrm{it}}$ & $\begin{aligned}= & \text { Local government head } \\
& \text { background at time } \mathrm{t}\end{aligned}$ \\
\hline$€_{\mathrm{i}}$ & $=$ Error term \\
\hline
\end{tabular}

\section{Operationalization of Variable}

To measure auditor quality, we use eleven auditor quality variables. Workload is measured by number of auditees assigned to audit team leader during a year. Year end is the peak season for BPK's auditor, because auditor has an obligation to report the audit results six months after the fiscal year end. According to Van Linden and Willekens (2013) workload of staff /partner is negatively related audit quality. Tenure is the length of time (in years) auditors audit the same entities. There is no formal rule of auditor rotation in BPK. A common practice for auditor rotation is every 5 years or less ( 3 years) if auditor is placed in conflict/remote area. Measurement of tenure used in this study is the length of time (in years) audits the same auditee. BPK regulation 4/2010 art 19 states that every auditor has a role in carrying out their duty. The role classifications from the lowest to the highest are junior team members; senior team members; junior team leader; senior team leader; technical control and quality control. The differences between junior and senior team leader is associated with complexity of the task. The role in auditor quality components is measured by identifying whether the audit team leaders have a role as junior/senior team members as requested by the BPK regulation.

As stated in general standard of SPKN that the staff assigned to carry out the examination should collectively have sufficient professional skills required for the task. Setyaningrum (2011) measure professional skills using the length of time (in years) auditor became audit team leader. Measurement of professionalism variable in this study follows Setyaningrum (2011) which are length of time (in years) as audit team leader and the length of time (in years) as BPK auditors. SPKN stated that in order to master the latest developments related to the role as auditor, BPK's auditor required to complete at least 80 hours of trainings every two years; whereas 24 hours of the 80 hours of trainings must be directly related to the audit tasks. Batubara (2008) found positive effect between continuing professional education with audit quality. To ensure that the auditor meets these requirements, BPK's education and training center provide education and training in accordance with the role of the auditor. Training variable measured by number of training hours and number of technical and functional training followed by audit team leader in a year. In order to understand the relevant accounting and auditing standards, auditor should have the academic and practical experience in the field of accounting. This study uses two variables to measure education, which are educational background and level of education. If audit team leader has accounting background, we give score of 1 and 0 if otherwise. Second variable is level of education, which is 1 if audit team leader has post-graduate degree and 0 if otherwise as used by Setyaningrum (2011).

Motivation is an important factor that should be considered as a determinant of audit quality, because in the public sector or risk dismissal for loss of reputation is very small considering the auditors is civil servants. Efendy (2010) measures motivation using auditors' perception, but none of the literature measured motivation using secondary data. This study proposes motivation measurement using percentage of the follow-up examination from previous period. As one of the BPK's key performance indicators, the auditor would be very concerned about the follow-up of audit recommendation.

Dependent variable for regression model is follow up of audit recommendation (TLRHP_NOM) measured by nominal value of recommendations completely followed-up plus recommendation that 
can not be followed-up divided by the total nominal value of recommendations. Lin and Liu (2012) measure the results of the rectification effort with the amount of funds remitted to the state treasury and the amount of the budget cut after an audit. In Indonesia, BPK cannot impose sanctions and penalties directly as is done in China. This study measures follow up on audit recommendation by adding nominal value of recommendations completely followed-up plus recommendation that cannot be followed-up divided by the total nominal value of recommendations. Followup recommendations are more focused on nominal value because based on the results of the examination (IHPS) from 2005 to 2013, the average percentage of nominal recommendations were followed uponly $27.34 \%$. Local government should prioritize follow-up which has a nominal value since it show the significance (importance) of the recommendation.

Auditor quality (AQ) will be developed using principal component analysis (PCA) as used by Cheng et al., (2013). PCA procedure is basically aimed to simplify variables by reducing its dimensions. From eleven auditor quality variables explained in previous part, then we reduce the variable into auditor quality component and will be grouped into factors that explain most variance in the data. This factor then will combine into a single index called Auditor Quality Index. Audit opinion (OPINI) is measured using an ordinal scale that can be sorted by ranking. In this study, the audit opinion is categorized from lowest to highest as follows: (1) Disclaimer Opinion (TMP), (2) Adverse Opinion (TW), (3) Qualified Opinion (WDP), and (4) Unqualified Opinion (WTP). This measurement is also used in Nuraeni (2011) and Wicaksono (2012). Audit findings (FINDING) were measured using nominal value of the audit findings. Nominal value of the findings reflects levels of findings materiality, thus reflecting the magnitude of the findings generated by the auditor. This proxy is also used in research Liestiani (2008) and Wicaksono (2012).

Size (SIZE) is log natural of local government total asset. Local government dependency (DEPEND) is measured by intergovernmental revenue transfer divided by total revenue. Population (POPL) is log natural of total population. The last two independent variables are age of local government (AGES) measured since establishment act of district/municipalities and local department head background (SUPP) with score of 1 if local government leader has economics/accounting background and 0 if others.

\section{RESULTS AND DISCUSSION}

\section{Descriptive Statitistics}

Descriptive statistic on auditor quality variables is presented on table 1 . Table 1 shows that in average, team leader perform financial audit to 1-2 auditee during a year and team leader never audit the same auditee more than twice. The frequency distribution shows that $67 \%$ of auditor has a functional position role as team leader (junior and senior). However, it is also found that $31 \%$ of the samples still have a role as team member. This fact should become BPK's concern to monitor adequacy of team leader especially in BPK's regional office because team leader was considered responsible of carrying out the audit field work, so that the ideal conditions can be fulfilled. In terms of educational background, as much as $88 \%$ auditor has accounting background, but only $27 \%$ were completed post graduate degree. In average, team leader has nine years experience as an auditor in BPK, and the average experience of being a team leader is 7.2 months. To be a junior team leader, auditor must first pass through a role as a junior and senior team member where each role level increase requires at least 3 years, taking into account the adequacy of the number of credits and the assessment by human resources department. If the average experience as BPK's auditor is 9 years, the auditor should already reach role as senior team leader, but in fact majority role of auditor in this sample is still as junior team member, so it can be concluded it takes more than 3 years to get promoted. Within a year, in average, team leader followed 2 training 
with total training hours of 65 hours. Training rules in the BPK mentioned that each year the auditor must follow minimum 40 hours of training related with the functional roles as auditor and other relevant trainings. The result shows that the training requirements for auditor have been met. The last variable is the recommendation follow-up (LTLRHP/LTLRHP_NOM) results showed that the number (nominal value) completed follow-up as recommended by auditor is $52.25 \%$ (41.08\%). This number is quite low, given the mandatory obligation for local governments to improve the quality of financial statements. If percentage of follow-up on audit recommendation on the previous period is low, it could probably decrease auditor motivation for the next assignment; since auditee does not committed to make an improvement. Followup on audit recommendation is one measure of implementation success of the tasks, functions and role of BPK in encouraging and managing the state's financial responsibility.

The results of auditor quality variable reduction using principal component analysis methods yielded four components with eigenvalues more than one and explained $62 \%$ of the total variance. The next four component will be given the name accordance with the substance of each of the component of the variables included, which are (1) Experience which consist of ROLE, PROF, EXP, and EDUC_2; (2) Training which consists of TRAIN_1 and TRAIN_2; (3) Motivation which consist of TLRHP, TLRHP_NOM and WORKLOAD; (4) Education which consist of EDUC_1 and TENURE. Furthermore, all four components combine into single auditor quality index based on the percentage of variance explained by each component, as follows:

$$
\begin{aligned}
\mathrm{AQ}= & 0.3533(\text { EXPERIENCE })+0.2910(\text { TRAINING }) \\
& +0.2040(\text { MOTIVATION })+0.1517 \\
& (\text { EDUCATION })
\end{aligned}
$$

The correlation of each auditor quality variables on auditor quality shows signifinicat positive result, except for workload (see table 2). These results indicate that the auditor quality will be higher if all the components receive full attention because

Table 1. Descriptive Statitistics for Auditor Quality Variables

\begin{tabular}{lrrrrr}
\hline & N & Minimum & Maximum & Mean & Std. Deviation \\
\hline WORKLOAD & 1496 & 1.00 & 3.00 & 1.255 & .461 \\
TENURE & 1496 & 1.00 & 3.00 & 1.047 & .214 \\
ROLE & 1449 & 1.00 & 4.00 & 2.761 & .657 \\
EDUC_1 & 1449 & .00 & 1.00 & .875 & .331 \\
EDUC_2 & 1449 & .00 & 1.00 & .270 & .444 \\
EXP & 1449 & .00 & 34.00 & 9.003 & 4.958 \\
PROF & 1449 & .00 & 5.00 & .597 & 1.255 \\
TRAIN_1 & 1552 & .00 & 12.00 & 2.061 & 1.755 \\
TRAIN_2 & 1552 & .00 & 475.00 & 65.400 & 56.113 \\
LTLRHP & 1553 & .00 & 1.00 & .523 & .292 \\
LTLRHP_NOM & 1522 & .00 & 1.00 & .411 & .358 \\
VALID N (listwise) & 1405 & & & & \\
\hline
\end{tabular}

Description:

WORKLOAD = Number of auditees assigned to audit team leader within a year; TENURE $=$ The length of time (in years) audit the same entities; ROLE $=$ The role of the team leader at the time of audit; $4=$ Senior Team Leader; $3=$ Junior Team Leader; 2 = Team Member; 1 = Other; EDUC_1 = Educational background audit team leader, 1 if the accounting and 0 if other; EDUC_2 = Qualification audit team leader, Level of education of audit team leader, $1=$ post-graduate degree and 0 $=$ others $; \mathrm{EXP}=$ The length of time (in years) as BPK's auditor; PROF = The length of time (in years) as audit team leader; TRAIN_1 = Number of training followed during a year; TRAIN_2 = Number of hours of training followed during a year; LTLRHP = Lag of number of recommendations completely followed-up plus that can not be followed-up divided by the total number of recommendations; LTLRHP_NOM = Lag of nominal value of recommendations completely followed-up plus that can not be followed-up divided by the total nominal value of recommendations 
it correlates significantly with the auditor quality Special attention should be given to workload, since it correlates negatively with auditor quality. Agoglia, et al., (2010), Lopez and Peters (2012) and Hansen, et al., (2008) support this finding and prove that audit capacity stress because of having many clients will result in decline of audit quality. In a year, BPK's auditor not only has to perform financial audit, but also performance audit, and other special audit (compliance audit or investigative audit). BPK should monitor the adequacy of human resources and balancing the auditor workload so quality of auditor work is not decreased. If we correlate all four components with Auditor Quality Index (AQ), all the components show significant positive correlation (two-tailed test) with auditor quality.

From Table 3 it can be seen that the average percentage of nominal value of follow up on audit recommendations during $2010-2012$ only $32.23 \%$. If we look further, there is a trend of decline in the percentage of follow-up on audit recommendations examination results both in number and nominal. Central government should emphasize more on monitoring follow-up to improve the quality of local government financial reports. The auditor quality tested in the main model is the auditor quality in prior period (lag). For example as illustrated in figure 1, TLRHP_NOM in 2012 contains follow-up done by the management during the 2012 based on audit findings in 2011; thus the auditor quality used is from 2011. Because of the lag, number of observation of auditor quality reduced to only 902 . Auditor quality in 2012 cannot be used because of the audited financial statements of year 2013 have not been published by the BPK.

Most local governments achieve qualified opinion, with the percentage in 2010, 2011 and 2012

Table 2. Correlation matrix of variable used to extract auditor quality

\begin{tabular}{|c|c|c|c|c|c|c|c|c|c|c|c|c|c|}
\hline & $\mathrm{AQ}$ & LTLRHP & LTLRHP & NOM & WORKLOAD & TENURE & ROLE & EDUC_1 & EDUC_2 & EXP & PROF & TRAIN_1 & TRAIN_2 \\
\hline$\overline{\mathrm{AQ}}$ & & $.305^{* *}$ & & $.245^{* *}$ & $-.128^{* *}$ & $.221^{* *}$ & $.608^{* *}$ & $.142^{* *}$ & $.399^{* *}$ & $.518^{* *}$ & $.431^{* *}$ & $.563^{* *}$ & $.504^{* *}$ \\
\hline LTLRHP & $.305^{k+1}$ & & & $.546^{* * *}$ & $-.189^{* * *}$ & -.038 & $.078^{*}$ & -.003 & .004 & $.072^{*}$ & -.039 & $.092^{* *}$ & .059 \\
\hline LTLRHP_NOM & $.245^{* *}$ & $.546^{* *}$ & & & $-.142^{* *}$ & -.005 & .063 & -.009 & -.002 & .051 & -.049 & $.071^{*}$ & .042 \\
\hline WORKLOAD & $-.128^{* * *}$ & $-.189^{* * *}$ & & $-.142^{* *}$ & & .030 & .044 & .015 & $.076^{\prime \prime}$ & .020 & .010 & -.029 & -.049 \\
\hline TENURE & $.221^{* *}$ & -.038 & & -.005 & .030 & & .047 & .041 & .010 & .029 & $.100^{* *}$ & .010 & -.013 \\
\hline$\overline{\text { ROLE }}$ & $.608^{* * *}$ & $.078^{*}$ & & .063 & .044 & .047 & & -.028 & $.344^{* *}$ & $.580^{* * *}$ & $.642^{* * *}$ & -.010 & -.053 \\
\hline EDUC_1 & $.142^{* *}$ & -.003 & & -.009 & .015 & .041 & -.028 & & -.061 & $-.108^{* *}$ & .010 & -.018 & -.026 \\
\hline EDUC_2 & $.399^{* *}$ & .004 & & -.002 & $.076^{*}$ & .010 & $.349^{* *}$ & -.061 & & $.388^{* *}$ & $.273^{* *}$ & .010 & -.017 \\
\hline EXP & $.518^{* *}$ & $.072^{*}$ & & .051 & .020 & .029 & $.580^{* *}$ & $-.108^{* *}$ & $.388^{* *}$ & & $.335^{* *}$ & .046 & -.014 \\
\hline PROF & $.431^{* *}$ & -.039 & & -.049 & .010 & $.100^{* * *}$ & $.642^{* * *}$ & .010 & $.273^{* *}$ & $.335^{* * *}$ & & $-.119^{* *}$ & $-.142^{* *}$ \\
\hline TRAIN_1 & $.563^{* *}$ & $.092^{* *}$ & & $.071^{*}$ & -.029 & .010 & -.010 & -.018 & .010 & .046 & $-.119^{* *}$ & & $.811^{* *}$ \\
\hline TRAIN_2 & $.504^{k+4}$ & .059 & & .042 & -.049 & -.013 & -.053 & -.026 & -.017 & -.014 & $-.142^{* * *}$ & $.811^{* * *}$ & \\
\hline
\end{tabular}

Notes: 1. Pearson (Spearman) correlation coefficient are in the lower (upper) triangle.

2. $* * * * *$ and $*$ denote significance at the $1 \%, 5 \%$, and $10 \%$ level respectively (two-tailed test).

3. LTLRHP/LTLRHP_NOM = (lag number (nominal value) of recommendation completely followed up)(total number (nominal value) recommendation); WORKLOAD = number of auditee assigned during a year; TENURE $=$ length of time (in years) audit the same auditee; ROLE $=$ role of team leader; $4=$ senior team leader; $3=$ junior team leader; 2 = team member; 1 = others; EDUC_1 = education background; 1 = accounting; $0=$ others; EDUC_2 $=$ level of education; $1=$ post graduate degree; $0=$ others; EXP $=$ length of time (in years) as auditor; PROF $=$ length of time (in years) as team leader; TRAIN_1 = number of training followed during a year ; TRAIN_2 $=$ number of training hours during a year.

Description:

WORKLOAD = Number of auditees assigned to audit team leader within a year; TENURE $=$ The length of time (in years) audit the same entities; ROLE $=$ The role of the team leader at the time of audit; $4=$ Senior Team Leader; $3=$ Junior Team Leader; 2 $=$ Team Member; 1 = Other; EDUC_1 = Educational background audit team leader, 1 if the accounting and 0 if other; EDUC_2 $=$ Qualification audit team leader, Level of education of audit team leader, $1=$ post-graduate degree and $0=$ others; EXP $=$ The length of time (in years) as BPK's auditor; PROF = The length of time (in years) as audit team leader; TRAIN_1 = Number of training followed during a year; TRAIN_2 = Number of hours of training followed during a year; LTLRHP = Lag of number of recommendations completely followed-up plus that can not be followed-up divided by the total number of recommendations; LTLRHP_NOM = Lag of nominal value of recommendations completely followed-up plus that can not be followed-up divided by the total nominal value of recommendations 
Table 3. Descriptive Statistics for Empirical Model

\begin{tabular}{lcrrrr}
\hline \multicolumn{1}{c}{ Variable } & Obs & Mean & Std. Dev & \multicolumn{1}{c}{ Min } & \multicolumn{1}{c}{ Max } \\
\hline TLRHP_NOM $^{1}$ & 1511 & 0.322 & 0.356 & 0 & 1 \\
AQ $_{\mathrm{t}-1}$ & 902 & 0.034 & 0.505 & -1.219 & 1.625 \\
OPINI $_{\mathrm{t}-1}$ & 1550 & 2.594 & 0.905 & 1 & 4 \\
FINDING t-1 (Rp mio) & 1578 & 19,903 & 170,655 & 29.04 & $6,431,585$ \\
SIZE t (Rp juta) & 1557 & 3,178 & 17,262 & 45,497 & 407,096 \\
DEPEND $_{\mathrm{t}}$ & 1557 & 0.881 & 0.123 & 0.223 & 2.078 \\
POPL $_{\mathrm{t}}$ & 1575 & 894,113 & $3,085,465$ & 6,144 & $44,349,449$ \\
AGES $_{\mathrm{t}-1}$ & 1575 & 36.278 & 22.837 & 0 & 62 \\
SUPP $_{\mathrm{t}-1}$ & 1575 & 0274 & 0.446 & 0 & 1 \\
\hline
\end{tabular}

Description:

TLRHP_NOMt $=$ Nominal value of recommendations completely followed-up plus recommendation that cannot be followedup divided by the total nominal value of recommendations; AQ t-1 = Lag Auditor Quality Index; OPINIt-1 = Lag Opinion 1: Disclaimer Opinion (TMP) , 2: Adverse Opinion (TW), 3: Qualified Opinion (WDP), 4: Unqualified Opinion (WTP); FINDING t-1 $=$ lag of the nominal value of the audit findings; SIZEt $=$ Log of Total Asset; DEPENDt $=$ Intergovernmental revenue transfer divided by total revenue; POPLt $=$ Log of number of population; AGESt $=$ Age of Local Government Administrative Since There Establishment Act Local Government District/City; SUPPt $=1$ if Local government head has economics/accounting background, $0=$ others

respectively by $65.33 \% ; 66.60 \%$ and $60.88 \%$. There is a tendency of increase in unqualified opinion from $6.51 \%$ in 2010 to $22.90 \%$ in 2012 . Meanwhile disclaimer and adverse opinion decreases over time. The improvement in the audit opinion deserves appreciation because local governments have attempted to improve the audit opinion from year to year. Nominal value of audit findings reflects the significance of the findings than the number of audit findings. Average nominal value of audit findings in a sample is Rp15.7 billion. There is a declining trend of nominal value of audit findings from Rp24.2 billion in 2009 to Rp 11.8 billion in 2012 .

An average total asset of local governments is Rp3.2 trillion. Dependence of local governments to the central government is also very high; it is proved by an average ratio of intergovernmental revenue transfer compared to total revenue reached $88.03 \%$. Based on the administrative age, the average age is 36 years with maximum age of 62 years. The average population is 894.113 inhabitants. Descriptive statistics also shows that $73 \%$ of heads of regions in Indonesia does not have a background in economics/accounting/finance.

\section{Auditor Quality and Follow-up of Audit Recommendation}

The results of hypothesis testing of the model are presented in Table 4.

The hypothesis of this study states that there is positive effect between auditor quality and follow-up on audit recommendation. Regression results from Table 6 support the hypothesis, which is indicated by the positive and significant effect with $1 \%$ level of confidence. These results indicate that high-quality auditors are able to produce appropriate recommendations that can be acted upon by the audited entity. This is in line with the recommendations mentioned in the report BPK performance management (2012) that the BPK's auditor are encouraged to formulate recommendations that can be acted upon by the audited entityso it reflects the effectiveness of the recommendations given.

GAO (1991) stated that when a recommendation is made to an auditee, management is basically responsible for implementing it. But auditors can do a great deal to improve the likelihood that a recommendation will be appropriately 
Table 4. Regresion Result of Hypothesis Testing

\begin{tabular}{|c|c|c|c|c|}
\hline TLRHP $_{t}$ & Expected Sign & Coef & $P>z$ & \\
\hline _cons & & 0.728 & 0.132 & \\
\hline $\mathrm{AQ}_{\mathrm{t}-1}$ & $(+)$ & 0.112 & 0.000 & $* * *$ \\
\hline OPINI $_{t-1}$ & $(+)$ & 0.023 & 0.058 & $*$ \\
\hline FINDING t-1 & $(-)$ & -0.075 & 0.000 & $* * *$ \\
\hline SIZE t & $(+)$ & -0.065 & 0.119 & \\
\hline DEPEND $_{\mathrm{t}}$ & $(+)$ & -0.038 & 0.374 & \\
\hline $\mathrm{POPL}_{t}$ & $(+)$ & 0.002 & 0.006 & $* * *$ \\
\hline $\mathrm{AGES}_{\mathrm{t}}$ & $(+)$ & 0.096 & 0.006 & $* * *$ \\
\hline $\mathrm{SUPP}_{\mathrm{t}}$ & $(+)$ & -0.016 & 0.279 & \\
\hline $\mathrm{N}$ & 846 & & & \\
\hline $\mathrm{R} 2$ & $17.05 \%$ & & & \\
\hline
\end{tabular}

Description:

1. $* * *, * * *$ shows significance level $1 \%, 5 \%, 10 \%$ (one-tailed test)

2. TLRHP_NOMt $=$ Nominal value of recommendations completely followed-up plus recommendation that cannot be followed-up divided by the total nominal value of recommendations; AQ t-1 = Lag Auditor Quality Index; OPINIt-1 = Lag Opinion 1: Disclaimer Opinion (TMP) , 2: Adverse Opinion (TW), 3: Qualified Opinion (WDP), 4: Unqualified Opinion (WTP); FINDING t-1 = lag of the nominal value of the audit findings; SIZEt $=$ Log of Total Asset; DEPENDt $=$ Intergovernmental revenue transfer divided by total revenue; POPLt $=$ Log of number of population; AGESt = Age of Local Government Administrative Since There Establishment Act Local Government District/Municipality; SUPPt = 1 if Local government head has economics/accounting background, $0=$ others

implemented by giving: (1) high quality recommendations: recommendation that does correct the basic cause of a deficiency, (2) commitment: committed to the need for action on a recommendation and do what needs to be done to get it implemented and (3) aggressive monitoring and follow-up: acceptance of a recommendation does not ensure results; continued attention is required until results are achieved. This regression result confirms all important point highlighted by GAO (1991) of the importance role of high quality auditor. High auditor quality reflects high auditor competence that can generate correct and appropriate recommendations that can correct basic cause of deficiency, so it could be effectively implemented by the auditee. Auditor should also have to monitor the follow-up because the more recommendations are acted upon, the better the quality of local government financial statements.
From the regression result, we also found that previous audit opinion has positive effect on follow-up of audit recommendation. As signaling theory stated, local government will maintain good audit opinion from previous year by increasing percentage of follow up of audit recommendation. This is done to send signal to the voters that local government has commitment to improve local financial management. We also found that previous audit finding has negative effect on follow up of audit recommendation. This result consistent with Lin and Liu (2012) who found that local government with high audit findings, the follow up of audit recommendation decreased, because local government need much more time to implement recommendation compare to local government with less recommendation. We also found positive effect of ages and population and follow-up on audit recommendation consistent with Copley (1991). Lesmana (2010) states that the 
Table 5. Regresion Result of Additional Testing

\begin{tabular}{|c|c|c|c|c|}
\hline TLRHP $_{t}$ & Expected Sign & Coef & $P>z$ & \\
\hline _cons & & 0.575 & 0.171 & \\
\hline EXPERIENCE t-1 & $(+)$ & 0.019 & 0.048 & $* *$ \\
\hline TRAINING t-1 & $(+)$ & 0.003 & 0.376 & \\
\hline MOTIVATION t-1 & $(+)$ & 0.138 & 0.000 & $* * *$ \\
\hline EDUCATION t-1 & $(+)$ & 0.006 & 0.289 & \\
\hline $\mathrm{OPINI}_{\mathrm{t}-1}$ & $(+)$ & 0.001 & 0.466 & \\
\hline FINDING t-1 & $(-)$ & -0.048 & 0.001 & $* * *$ \\
\hline SIZE t & $(+)$ & -0.053 & 0.148 & \\
\hline DEPEND $_{t}$ & $(+)$ & 0.070 & 0.269 & \\
\hline $\mathrm{POPL}_{t}$ & $(+)$ & 0.001 & 0.035 & $* *$ \\
\hline $\mathrm{AGES}_{\mathrm{t}}$ & $(+)$ & 0.074 & 0.019 & $* *$ \\
\hline $\mathrm{SUPP}_{\mathrm{t}}$ & $(+)$ & -0.011 & 0.33 & \\
\hline $\mathrm{N}$ & 846 & & & \\
\hline $\mathrm{R} 2$ & $17.05 \%$ & & & \\
\hline
\end{tabular}

Description:

1. $* * *, * *, *$ shows significance level $1 \%, 5 \%, 10 \%$ (one-tailed test)

2. TLRHP_NOMt $=$ Nominal value of recommendations completely followed-up plus recommendation that cannot be followed-up divided by the total nominal value of recommendations; AQ t-1 = Lag Auditor Quality Index; OPINIt-1 = Lag Opinion 1: Disclaimer Opinion (TMP) , 2: Adverse Opinion (TW), 3: Qualified Opinion (WDP), 4: Unqualified Opinion (WTP); FINDING $\mathrm{t}-1=$ lag of the nominal value of the audit findings; SIZEt $=$ Log of Total Asset; DEPENDt $=$ Intergovernmental revenue transfer divided by total revenue; POPLt $=$ Log of number of population; AGESt = Age of Local Government Administrative Since There Establishment Act Local Government District/Municipality; SUPPt = 1 if Local government head has economics/accounting background, $0=$ others

longer the age of local government, the higher the experience from local governments in running the administrative system, including financial reporting process, so it will increase capabilities of local government to follow-up audit recommendation. Patrick (2007) argue that local government that has leader with economic/accounting background understand accounting standard and able to prepare high quality financial statement. They also assumed to be more committed on follow-up on audit recommendation in order to continually improve accountability of local government financial management. Unfortunately, in this research, leader's economic and accounting background does not have any effect on followup of audit recommendation. If we looked at the descriptive statistics, percentage of leaders with economic/accounting background only $27 \%$ out of total sample. This condition can probably explain why we found no effect for this variable.

\section{Additional Analysis}

Additional tests performed to see the effects of individual auditor quality variables on audit rectification. The results of the regression can be seen in Table 5.

Table 5 shows additional test result of the effect of auditor quality components extracted from principle component analysis on follow-up of audit recommendation. The test results show that experience and motivation component that has positive effect on follow-up of audit recommendation. Experience shows competency 
of auditor; the higher the competency the better the quality of audit recommendation that correct cause of deficiency and can be effectively implemented by auditee. Motivation also has positive effect on follow up of audit recommendation; thus this result confirms that motivation is one of the important aspects that should be considered to increase auditor quality ${ }^{1}$.

\section{MANAGERIAL IMPLICATIONS}

Result of this study implies that the responsibility to follow-up audit recommendation not only become single responsibility of local government. Auditor can take an active role by continually strive to improve the competencies. These roles will in turn improve the quality of financial statements. Specifically, this research is the first study in Indonesia that use auditor quality to measure audit quality in public sector. Auditor quality index developed in this study is useful for the next research to measure the auditor quality as well as audit quality that as far as our concern the research is limited. This study is also useful for BPK because we present comprehensive picture of auditor competence especially audit team leader. It is found is this research that not all field work auditor in charge has a role as audit team leader, some of the auditors do not engage in compulsory training and less of them has post graduate degree. This is valuable input for BPK in quality assurance process to ensure all audit team leader has high competence as in this research shows positive effect on high quality of financial statements.

\section{CONCLUSION}

The first purpose of this study is to measure auditor quality of BPK auditor who audits local governments' financial statements. According to Watkins et al., (2004), audit quality can be measured by the auditor quality; where the auditor quality represents competency of human capital. There are 11 (eleven) variables enter in this study expected to affect the auditor quality. Using principle component analysis method, the result shows that variable can be reduced into four components that form auditor quality namely experience, training, motivation, and education. All four components are then combined into a single auditor quality index that represents comprehensive measure of auditor quality.

The second objective of this study is to examine the effect of auditor quality on follow-up of audit recommendation. High auditor quality reflects high auditor competence that can generate correct and appropriate recommendations that can correct basic cause of deficiency, so it could be effectively implemented by the auditee. Auditor should also monitor the follow-up because the more recommendations are acted upon, the better the quality of local government financial statements. These results prove that the auditor quality will have a positive effect on the follow-up of audit recommendation. In the additional test, we found that experience and motivation component shows positive effect on the follow-up of audit recommendation. Overall, it can be concluded auditor can take role on increasing follow-up of audit recommendation by formulating appropriate recommendation, and to do so auditor should continue improving their competencies.

There are several limitations of this study. First, in this study, independence have been considered by including the tenure variable, and the results shows that in average, auditor are regulary rotated, so he/she does not audit the same auditee more than two times in a row, so that the auditor independence is not threatened. However, further research can use primary data to measure more precisely the auditor independence and test the

1. To further investigate the correlation between motivation and auditor quality, we made sub-sample data where the audit team leader perform audit for the same entities more than once, to ensure that the same team leader monitor follow up their previous recommendation. The results of the correlation test shows a significant positive correlation, 
effect on auditor quality. Second, numbers of audit findings use in this study do not classify findings according to type of audit finding and progress of audit findings. Further research can extend this research by focusing on type and progress of audit findings to see whether our main variable robust with different audit findings measurement.

Following up auditor recommendations is one of the efforts to improve the audit opinion. The greater the percentage of recommendations is acted upon, the better the accountability of financial managementand it gives impact on better audit opinion in the next period. Lin and Liu (2012) hypothesized that the government audit institution with competent and independent auditors should be able to better detect irregularities so that the number of findings reported are higher. Future studies are expected to examine the effect of the auditor quality on auditor's opinion and findings, either directly or indirectly through percentage of follow up on audit recommendation.

meaning the completion of the auditor's recommendations given in the previous period increase the motivation of auditors to do a better job on the next audit.

\section{REFEREN CES}

Agoglia, C. P., Brazel, J. F., Hatfield, R. C., \& Jackson, S. B. (2010). How do audit workpaper reviewers cope with the conflicting pressures of detecting misstatements and balancing client workloads? Auditing: A Journal of Practice \& Theory, 29(2), $27-43$

Asian Organization of Supreme Audit Institutions. (ASOSAI). (2009). Quality assurance in financial audit handbook.

Bennis, W. (2003). The emotionally intelligent workplace: how to select for, measure, and improve emotional intelligence in individuals, groups, and organizations. C. Cherniss, \& D. Goleman (Eds.). John Wiley \& Sons.

Chi, W., Lisic, L. L., \& Pevzner, M. (2011). Is?. Accounting Horizons, 25(2), 315-335. enhanced audit quality associated with greater real earnings management

Cheng, Yu-Shu, Yahn-Shir Chen dan Yu-Cheng Chen. (2013). Direct and mediating effects of auditor quality on auditor size and performance. International Business Research; Vol. 6, No. 11

Choo, F., \& Trotman, K. T. (1991). The relationship between knowledge structure and judgments for experienced and inexperienced auditors. Accounting Review, 464-485.

Clark, C., De Martinis, M., \& Krambia-Kapardis, M. (2007). Audit quality attributes of european union supreme audit institutions. European Business Review, 19(1), 40-71.

Cohen, S., \& Leventis, S. (2013, March). Effects of municipal, auditing and political factors on audit delay. In Accounting Forum (Vol. 37, No. 1, pp. 40-53). Elsevier.

Davis, L. R., Soo, B., \& Trompeter, G. (2002). Auditor tenure, auditor independence and earnings management. Working paper, Boston College, Chestnut Hill, MA.

DeAngelo, L. E. (1981). Auditor size and audit quality. Journal of accounting and economics, 3(3), 183-199.

Dopuch, N., King, R. R., \& Schwartz, R. (2001). An experimental investigation of retention and rotation requirements. Journal of Accounting Research, 39(1), 93-117.

Efendy, Muh. Taufik, 2010, The effect of competence, motivation and auditor's independence on audit quality (Empirical Study on Government of Gorontalo). Thesis Master of Science in Accounting, Universitas Diponegoro, Unpublished.

European Organization of Supreme Audit Institutions. (EUROSAI). (2004). Guidelines on Audit Quality

Hansen, S. C., Kumar, K. R., \& Sullivan, M. W. (2008). auditor capacity stress and audit quality: market-based evidence from andersen's indictment. Available at SSRN 1092874. 
Johnson, V. E., Khurana, I. K., \& Reynolds, J. K. (2002). Audit-Firm tenure and the quality of financial reports*. Contemporary accounting research, 19(4), 637-660.

Jones III, A., Norman, C. S., \& Wier, B. (2010). Healthy lifestyle as a coping mechanism for role stress in public accounting. Behavioral Research in Accounting, 22(1), 21-41.

Laswad, F., Fisher, R., \& Oyelere, P. (2005). Determinants of voluntary Internet financial reporting by local government authorities. Journal of Accounting and Public Policy, 24(2), 101-121.

Lesmana, S. I. (2010). The effect of local government characteristics on compulsory disclosure in Indonesia. Universitas Sebelas Maret. http://eprints.uns.ac.id/6/1/169921211201009511.pdf

Liu, J., \& Lin, B. (2012). Government auditing and corruption control: Evidence from China's provincial panel data. China Journal of Accounting Research, 5(2), 163-186.

López, D. M., \& Peters, G. F. (2012). The effect of workload compression on audit quality. Auditing: A Journal of Practice \& Theory, 31(4), 139-165.

Ministry of Internal Affair Decree No. 13/2010 about Guidance on Oversight Function of Legislature towards Follow-up of Audit Result of the Audit Board of the Republic of Indonesia

Ministry of Internal Affair Decree No. 20/2010 about Road Map of Bureaucratic Reform 2010-2014

Nuraeni. (2011). The analysis of local government charactristics on audit quality in indonesia local government 2008-2009. Undergraduate Thesis. Universitas Indonesia, Depok. Unpublished

Ogul, M. S., \& Rockman, B. A. (1990). Overseeing oversight: new departures and old problems. Legislative Studies Quarterly, 5-24.

Presidential Decree No.74/2001 about Monitoring on Local Government Functions.

Presidential Decree No. 81/2010 about Grand Design of Bureaucratic Reform 2010-2025.

Petrovits, C., Shakespeare, C., \& Shih, A. (2011). The causes and consequences of internal control problems in nonprofit organizations. The Accounting Review, 86(1), 325-357.

Republik Indonesia. Law No 15/2006 about The Audit Board of the Republic of Indonesia.

Republik Indonesia. Law No 15/2004 about Audit on the State Finance Management and Responsibility.

Republik Indonesia. Law No. 17/ 2003 about State Finance.

Republik Indonesia.Law No 8/2012 about General Election of Central and Provincial/District/Municipalities Legislative Member.

Setyaningrum, Dyah. (2011). Factors affecting BPK's audit quality. Presented in Simposium Nasional Akuntansi XV Banjarmasin, 20-23 September 2012

Streim, H. (1994). Agency problems in the legal political system and supreme auditing institutions. European Journal of Law and Economics, 1(3), 177-191.

The Audit Board of the Republic of Indonesia. (2007). Regulation of Badan Pemeriksa Keuangan Republik Indonesia No. 01/2007 about State Finance Auditing Standard.

The Audit Board of the Republic of Indonesia. (2008). Regulation of Badan Pemeriksa Keuangan Republik Indonesia No. 01/ 2008 about Use of Expert and External Auditor other than Auditor of The Audit Board of the Republic of Indonesia.

The Audit Board of the Republic of Indonesia. (2010). Regulation of Badan Pemeriksa Keuangan Republik Indonesia No. 04/2010 about Audit Functional Role in The Audit Board of the Republic of Indonesia.

The Audit Board of the Republic of Indonesia. (2013). Summary of Audit Reports Semester 1/2013. Jakarta: Badan Pemeriksa Keuangan RI

The Audit Board of the Republic of Indonesia. (2013). Summary of Audit Reports Semester 2/2013. Jakarta: Badan Pemeriksa Keuangan RI

The Audit Board of the Republic of Indonesia. (2012). Summary of Audit Reports Semester 1/2012. Jakarta: Badan Pemeriksa Keuangan RI.

The Audit Board of the Republic of Indonesia. (2012). Summary of Audit Reports Semester 2/2012. Jakarta: Badan Pemeriksa Keuangan RI.

The Audit Board of the Republic of Indonesia. (2009). Guidance on Quality Assurance System. Jakarta: Badan Pemeriksa Keuangan RI.

Van Linden, C. dan M. Willekens. (2013). The relationship between human resources practices and audit quality. Working paper, Katholieke Universiteit Leuven

Watkins, A. L., Hillison, W., \& Morecroft, S. E. (2004). Audit quality: a synthesis of theory and empirical evidence. Journal of Accounting Literature, 23(1), 153-193.

Wicaksono, Panggah Tri. (2012). Analysis of factors affecting audit opinion and audit findings on local government financial statement year 2008-2009. Undergraduate Thesis. Universitas Indonesia, Depok. Unpublished. 